\title{
Ontogenetic Change in Dietary Selection for Protein and Lipid by Gypsy Moth Larvae
}

\author{
BRIAN A. STOCKHOFF*-†
}

Received 8 September 1992; revised 15 January 1993

\begin{abstract}
Physiological changes during insect ontogeny should be manifest in changes in nutrient requirements and food preference. To investigate ontogenetic changes in food preference and digestive physiology, third- through sixth-instar gypsy moth larvae were provided choices among artificial diets differing in protein and lipid concentrations. Control larvae received two identical cubes of diet that were nutritionally complete, each containing a balanced mixture of protein and lipid. A second group of larvae received two different but complementary cubes, one deficient only in protein, the other deficient only in lipid. During early to late instars, preference shifted away from lipid-deficient, high protein cubes toward protein-deficient, high lipid cubes. This is consistent with the need for late-instar larvae to accrue energy reserves and specific fatty acids required during the pupal and non-feeding adult stages. Male larvae ate a higher proportion from the protein-deficient, high-lipid cube than females, possibly the result of greater energy demands by adult males. Female larvae tended to grow faster on deficient, complementary cubes than larvae provided complete cubes, despite poorer food utilization efficiency. These shifts and sex-specific variations in preference for protein and lipid likely reflect changing nutrient demands and fundamental physiological differences.
\end{abstract}

Food preference Ontogeny Protein Nitrogen Lipid Lymantria dispar

\section{INTRODUCTION}

Phytophagous insects typically must contend with nutritional variation arising from two major sources. First, the nutritional quality of host plants (i.e. the quantity and balance of nutrients) varies over time and among tissues, leaves, plants and species. As a result of such environmental variation, insects are faced with a constantly changing array of diet choices over their lifetime. Second, the nutritional requirements of insects change over time by virtue of shifting demands such as growth, reproduction and migration. For insects that experience heterogeneity in food nutrient content and developmental changes in nutrient requirements, compensation is necessary to avoid consequences such as reduced fecundity, prolonged development and early mortality.

Compensation for variation is possible both behaviourally (pre-ingestively) and physiologically (postingestively) (Simpson and Simpson, 1990). Behavioural compensation has been demonstrated in that some insects have the capacity to compensate for nutritional heterogeneity by selective feeding (Waldbauer and Friedman, 1988, 1991). By adjusting feeding in response to current nutritional requirements and available foods, these "self-selectors" are capable of mixing foods so as

\footnotetext{
*Department of Biology, University of Michigan, Ann Arbor, MI 48109-1048, U.S.A

†Current address: Mycogen Corporation, 4980 Carroll Canyon Road, San Diego, CA 92121 , U.S.A.
}

to achieve a more favourable balance of nutrients than could be obtained by random feeding or by consuming foods in other combinations. However, this type of compensatory response has been examined during only short, and not necessarily representative, portions of the insects' lives. Further, the specific behavioural mechanisms by which feeding activity might change during juvenile development have not been studied for any insect. Physiological compensation is possible by adjusting digestive efficiency or the efficiency of conversion of digested food into body tissue. Changes during larval development in food utilization efficiency have been observed (Slansky and Scriber, 1985), but measurements generally are from insects that are not permitted to alter their dietary intake through selection over time. Whether observed changes in utilization reflect compensation that is independent of food choice (i.e. would occur even if food choice were permitted) or are phenomena that occur only when behavioural compensation is inhibited is not known. If the latter is true, then a different pattern of change in food utilization during ontogeny would be expected in situations where food choice is possible than when food choice is not possible.

In this study I examined ontogenetic changes in both behaviour and physiology by larvae of the gypsy moth, Lymantria dispar (L.) (Lepidoptera: Lymantriidae). For behaviour, the goal was to determine if, when provided with identical choices in each instar, selection by larvae for protein and lipid changed during juvenile 
development. Because nutritional requirements likely change during development as non-reproductive growth demands diminish and energy storage needs increase, it was predicted that preference would shift from protein to lipid over successive instars and that individuals would benefit from this behaviour. Also, because allocation to reproduction occurs exclusively during the juvenile stages (adults do not feed), it was anticipated that males and females would differ in the extent of this shift. With regard to physiology, the goal was to assess potential compensatory changes in food consumption and utilization efficiency that might accompany changes in preference. Measures of developmental period, larval and pupal mass, and adult longevity provided estimates of the benefits of selectivity.

\section{MATERIALS AND METHODS}

\section{Artificial diet treatments}

Four diet treatments were established in which larvae were provided with two cubes of artificial diet, designated $\mathbf{A}$ and $\mathbf{B}$ (Table 1). Control larvae received two identical cubes of diet that were each nutritionally complete and contained a balanced mixture of protein and lipid at levels known to permit satisfactory growth. A second set of larvae received two different cubes, one deficient in protein (P) and the other deficient in lipid (L). Each cube otherwise was nutritionally complete. This treatment with complementary diet cubes was designated as Comp $P / L$. In the two remaining treatments larvae were provided with two identical cubes of either low protein (Low P/P) or low lipid (Low L/L) diet.

Diet formulations were modifications of the Bell diet for gypsy moth (Odell et al., 1985). Common to each diet were the following ingredients (per litre of finished diet): wheat germ $(30.6 \mathrm{~g})$, BioServ lepidopteran salt mix $(7.8 \mathrm{~g})$, choline chloride $(0.6 \mathrm{~g})$, ascorbic acid $(5.5 \mathrm{~g})$, $p$-methylhydroxybenzoic acid $(1.2 \mathrm{~g})$, sorbic acid $(2.2 \mathrm{~g})$, dextrose $(3.3 \mathrm{~g})$, soluble potato starch $(20 \mathrm{~g})$, BioServ lepidopteran vitamin mix $(0.8 \mathrm{~g})$, agar $(25 \mathrm{~g})$, and distilled, deionized water $(805 \mathrm{ml})$. Diets differed in vitamin-free casein concentration and linseed oil. High protein/high lipid diet used in the Control treatment contained $25 \mathrm{~g}$ of casein and $8 \mathrm{~g}$ of linseed oil. Low protein/high lipid and high protein/low lipid diets

TABLE 1. Composition of diet cubes A and B for the four diet treatments.

\begin{tabular}{|c|c|c|}
\hline $\begin{array}{l}\text { Diet } \\
\text { treatment* }\end{array}$ & Cube A & Cube $\mathrm{B}$ \\
\hline Control & $\begin{array}{l}\text { High protein/ } \\
\text { high lipid }\end{array}$ & $\begin{array}{l}\text { High protein/ } \\
\text { high lipid }\end{array}$ \\
\hline Comp P/L & $\begin{array}{c}\text { Low protein/ } \\
\text { high lipid }\end{array}$ & $\begin{array}{l}\text { High protein/ } \\
\text { low lipid }\end{array}$ \\
\hline Low $\mathrm{P} / \mathrm{P}$ & $\begin{array}{l}\text { Low protein/ } \\
\text { high lipid }\end{array}$ & $\begin{array}{l}\text { Low protein/ } \\
\text { high lipid }\end{array}$ \\
\hline Low $L / L$ & $\begin{array}{l}\text { High protein/ } \\
\text { low lipid }\end{array}$ & $\begin{array}{l}\text { High protein/ } \\
\text { low lipid }\end{array}$ \\
\hline
\end{tabular}

*P, Protein; L, lipid. contained 5 and $25 \mathrm{~g}$ casein $\mathrm{I}^{-1}$, respectively, and 8 and $0 \mathrm{~g}$ linseed oil $\mathrm{l}^{-1}$. Additional protein and lipid originated from wheat germ (BioServ), which contains approx. $25 \%$ protein and $12 \%$ lipid. Low and high protein diets thus contained a total of 10 and $20 \%$ protein, respectively. Low and high lipid diets contained a total of 1.8 and $5.8 \%$ lipid, respectively. Changes in protein were not completely balanced by alteration in lipid, and vice versa. To prevent dilution of other components as protein and lipid were altered, non-nutritive cellulose was added in amounts of $59.7,79.7$ and $67.7 \mathrm{~g} \mathrm{l}^{-1}$ to Control, low protein/high lipid, and high protein/low lipid diets, respectively.

\section{Larvae}

Gypsy moth egg masses were collected from a newlyinfested forest in Roscommon Co., Michigan, U.S.A. during winter 1991. Eggs were maintained in the dark at $5^{\circ} \mathrm{C}$ until hatching. Just prior to hatching, masses were surface-sterilized for $1 \mathrm{~h}$ in a $3.7 \%$ formalin solution to kill nucleopolyhedrosis virus adhering to the surface. Following disinfection, eggs were rinsed in running tap water for $1 \mathrm{~h}$ and then air-dried. Hatching and rearing were in an incubator at $25^{\circ} \mathrm{C}$ with a $16 \mathrm{~h}$ light $-8 \mathrm{~h}$ dark cycle. Relative humidity was maintained at approx. $75 \%$.

Neonates from four egg masses hatching simultaneously were placed individually into $30 \mathrm{ml}$ plastic cups with lids for rearing. Individuals immediately were assigned randomly to diet treatments. Twenty larvae (five from each egg mass) were assigned to Control and Comp P/L diet treatments for each of instar three, four and five to provide measures of food choice and utilization. Because males have five instars and females have six, only half of the larvae originally assigned to instar six were expected to enter a sixth instar. Therefore, 40 larvae were assigned to the sixth-instar Control and Comp P/L treatments to ensure a full complement of approx. 20 larvae. Twenty larvae were assigned to the Low P/P and Low L/L treatments for food choice and utilization measures which were made only during the fourth instar. An additional 80 larvae were reared on each of the four diet treatments. These individuals provided larvae and pupae for fresh to dry mass conversions (approx. $n=12$ per treatment per instar) or were reared to adults to provide supplemental measures of juvenile period, pupal mass, pupal period and adult longevity.

\section{Food choice, nutritional index measurements}

Food choice was measured during the first 3 days of instars three through six. Upon entry to the assigned instar, larvae were weighed, transferred to new rearing cups $(100 \times 15 \mathrm{~mm}$ plastic Petri dishes for sixth-instar larvae) and two diet cubes of approximately equal fresh mass were provided. Cubes were designated randomly as $A$ and $B$ in treatments where cubes were identical in nutrient composition. In the Comp $P / L$ treatment, the low protein/high lipid cube was designated as cube $A$. To 
avoid bias caused either by relative diet position or treatment location within the incubator, diets were placed opposite each other in a random arrangement within rearing cups, and trays of cups were shifted daily in their position within the incubator.

Food choice trials were terminated under any of three conditions: (1) larvae initiated moult or pupation to the next instar/stage, (2) $>80 \%$ of either diet cube was consumed, or (3) after 3 days, whichever came first. These conditions minimized disturbance to larvae (which might affect food choice), reduced potential effects of changes in relative abundance of diet types on preference, and ensured that assays were made over a similar period of time. It should be noted that, because instar duration increased from early to late instars, standardization of measurement over 3 days meant that food choice was measured over increasingly smaller proportions of an instar. Upon termination of a food choice trial, uneaten food was removed, dried to constant mass at $60^{\circ} \mathrm{C}$, and weighed.

Food consumption and utilization were measured over the entire instar. If a larva was not yet entering a moult or pupating at the time when the food choice trial was terminated, two weighed diet cubes were provided as before and replenished approximately every 2 days until initiation of a moult. An aliquot of each diet was taken each day to determine percentage dry mass for fresh to dry mass conversion. Upon reprovisioning and at the end of the instar, all uneaten diet and frass were collected, dried at $60^{\circ} \mathrm{C}$ and weighed. Larvae were weighed just prior to moulting. Rearing on diet treatments continued until pupation, and juvenile development time, pupal development time, and adult longevity were measured for all surviving individuals.

Food consumption over an entire instar was used in the calculation of consumption and food utilization indices. Calculation of indices was on a dry mass basis and used arithmetic mean larval mass according to Waldbauer (1968). Food ingested and frass were adjusted for AD, ECI and ECD to exclude the $\alpha$-cellulose, which is undigestible. Indices were:

RCR: Relative consumption rate

$$
=\frac{\text { food ingested }}{\text { mean larval mass } \times \text { days }} \text {. }
$$

RGR: Relative growth rate $=\frac{\text { biomass gained }}{\text { mean larval mass } \times \text { days }}$.

AD: Assimilation efficiency $=\frac{\text { food ingested-frass }}{\text { food ingested }} \times 100$.

ECI: Net growth efficiency $=\frac{\text { biomass gained }}{\text { food ingested }} \times 100$.

ECD: Gross growth efficiency

$$
=\frac{\text { biomass gained }}{\text { food ingested-frass }} \times 100 \text {. }
$$

\section{Data analysis}

Because no single measure of consumption accurately reflects choice behaviour, food choice data were analysed by two statistics. First, Chesson's $\alpha$ (Chesson, 1983; Lechowicz, 1982) was calculated as an index of food choice using the form:

$$
\alpha=\frac{r_{i} / n_{i}}{\sum_{j=1}^{m} r_{j} / n_{j}}, \quad i=1, \ldots, m,
$$

where $r_{i}$ and $n_{i}$ are the percentage of food type $i$ in the diet and environment, respectively, and $m$ is the number of food types available. Chesson's $\alpha$ was calculated for diet cube $A$ in treatments in which cubes were identical (Control, Low P/P, Low L/L) and low protein/high lipid cubes where cubes were complementary (Comp P/L). This number was compared with an expected value of $1 / m$, where $m=2$, the number of cubes provided. An $\alpha$ significantly different from expected indicates the food type was consumed out of proportion to its relative abundance. Because the masses of diet cubes provided to individuals were more or less the same, Chesson's $\alpha$ is approximately equivalent to the percentage that each diet cube contributed to the total eaten.

A second measure of food choice was a Levene's test for equality of variance [Van Valen (1978), as modified by Waldbauer and Friedman (1988)]. The percentage that each diet cube contributed to the total food eaten was calculated, and the average difference between these was found. This modified Levene's number was compared between treatments. A large mean difference between cubes yields a large modified Levene's number and indicates that individuals consumed the diet cubes in very different amounts. A small modified Levene's number indicates that feeding by individual larvae was divided evenly between the diet cubes. Note that, unlike Chesson's $\alpha$, the modified Levene's number is sensitive to the difference in amount consumed between the cubes and is insensitive as to which cube is consumed. For example, if $70 \%$ of the total amount eaten came from one of the two cubes, the modified Levene's number would be the same $(0.7-0.3=0.4)$ regardless of which cube contributed the $70 \%$.

Because multiple factors were of interest, including diet treatment, instar and sex, data were analysed by ANOVA followed by contrasts ( $\alpha$ adjusted for multiple comparisons by the Bonferoni method). To conform to assumptions underlying ANOVA, homogeneity of variances were tested via Bartlett's test $(\alpha=0.05)$ and normality of residuals tested by probability plots. Assumptions of ANOVA were satisfied except where noted. Where data could not reasonably be analysed and interpreted via ANOVA, non-parametric KruskalWallis tests were employed followed by pairwise comparisons using Mann-Whitney $U$-tests.

Before testing for Control vs Comp $\mathrm{P} / \mathrm{L}$ treatment effects and instar effects on food consumption and utilization, tests for homogeneity of variances indicated 
that data transformations were needed for certain variables. To pass Bartlett's test for homogeneity of variances $(\alpha=0.05)$, for males, RCR, AD, RGR, instar duration and mass gained were log-transformed. ECD of males was square root-transformed. For females, RCR, $\mathrm{AD}$, instar duration and mass gained were logtransformed. For females, ECD, ECI, instar duration and mass gained, inconsistent differences in variance prevented complete homogeneity of variance from being achieved $(P<0.05)$ so that ANOVA results for these variables should be treated with caution. However, the majority of differences indicated by ANOVA were large and are readily apparent by inspection of treatment means in the tables provided.

In tests for differences among all four treatments by fourth-instar larvae, sex was included as a factor in ANOVA models, necessitating different transformations. For these ANOVAs, RCR, AD, RGR and instar duration were log-transformed while ECD and ECI were reciprocal-transformed to pass Bartlett's test $(P>0.05)$.

\section{RESULTS}

\section{Food selection}

In the Comp $\mathrm{P} / \mathrm{L}$ treatment (in which larvae could select between complementary cubes, one low protein/high lipid, the other high protein/low lipid) larvae became less biased in selection over successive instars, with preference shifting from the high protein/low lipid cube to a more even mixture of the high protein/low lipid cube and the low protein/high lipid cube. Cubes in the Comp $\mathrm{P} / \mathrm{L}$ treatment were consumed by males and females in a different pattern than were cubes in the Control treatment (Table 2: Chesson's $\alpha$ ). This difference

TABLE 2. ANOVAs of food choice measures taken during instars 3-6 for Control and Comp P/L male and female larvae

\begin{tabular}{|c|c|c|c|c|c|}
\hline $\begin{array}{l}\text { Food choice } \\
\text { measure }\end{array}$ & Sex & Source & d.f. & $F$ & $\boldsymbol{P}$ \\
\hline \multirow{9}{*}{$\begin{array}{l}\text { Chesson's } \\
\alpha\end{array}$} & \multirow[t]{4}{*}{ Male } & Treatment & 1 & 5.67 & 0.023 \\
\hline & & Instar & 2 & 1.26 & 0.298 \\
\hline & & $\begin{array}{r}\text { Treatment } \\
x \text { instar }\end{array}$ & 2 & 3.05 & 0.061 \\
\hline & & Error & 33 & & \\
\hline & \multirow[t]{5}{*}{ Female } & Treatment & 1 & 4.79 & 0.031 \\
\hline & & Instar & 3 & 4.18 & 0.008 \\
\hline & & Treatment & & & \\
\hline & & $x$ instar & 3 & 3.77 & 0.013 \\
\hline & & Error & 97 & & \\
\hline \multirow{8}{*}{$\begin{array}{l}\text { Modified } \\
\text { Levene's } \\
\text { number }\end{array}$} & \multirow[t]{4}{*}{ Male } & Treatment & 1 & 0.03 & 0.866 \\
\hline & & Instar & 2 & 3.32 & 0.049 \\
\hline & & $x$ instar & 2 & 0.90 & 0.417 \\
\hline & & Error & 33 & & \\
\hline & \multirow[t]{4}{*}{ Female } & Treatment & 1 & 1.31 & 0.254 \\
\hline & & $\begin{array}{l}\text { Instar } \\
\text { Treatment }\end{array}$ & 3 & 3.34 & 0.022 \\
\hline & & $x$ instar & 3 & 1.31 & 0.276 \\
\hline & & Error & 97 & & \\
\hline
\end{tabular}

See text for an explanation of Chesson's $\alpha$ and the modified Levene's number

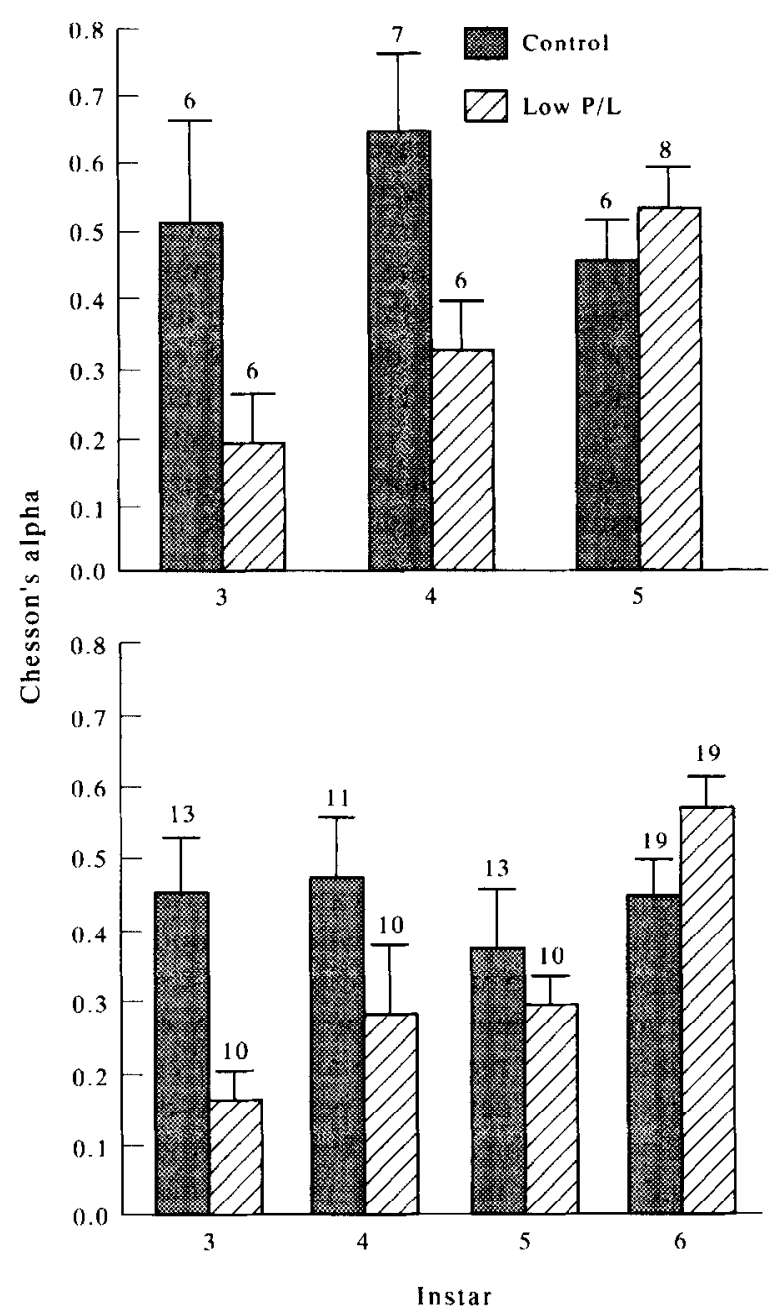

FIGURE 1. Ontogenetic change in food choice behaviour of male (upper panel) and female (lower panel) gypsy moth larvae as measured by Chesson's $\alpha$. Chesson's $\alpha$ corresponds roughly to the percentage that diet cube A (in the Control group) or the low protein cube (in the Comp P/L treatment) contributed to the total amount eaten. Plotted are means with standard errors of the mean; sample sizes are above each bar.

was dependent on the instar (note treatment $x$ instar interaction terms). Overall, cubes in the Control treatment were consumed across instars such that each cube contributed approx. $50 \%$ to the total amount eaten (Fig. 1: $\quad F_{2,16}=0.80, P=0.464$ and $F_{3,52}=0.35$, $P=0.792$ for males and females, respectively). In the Comp P/L treatment, however, low protein/high lipid diet was eaten in relatively small amounts during early instars, but contributed a much greater proportion to the total amount eaten in later instars (Fig. 1: $F_{2,17}=4.90$, $P=0.021$ and $F_{3.45}=9.48, P<0.0001$ for males and females, respectively). All larvae tended to eat more from both cubes of diet in later instars, regardless of whether the cubes were identical (Control) or complementary (Comp P/L) (modified Levene's number: Table 2, Fig. 2). Within a given instar, females consistently ate a slightly lower proportion from the low protein/high lipid cube than did males (Fig. 1; $F_{1.94}=3.98, P=0.049$ with no significant sex interaction with instar or treatment (all $P>0.1$ ); e.g. compare 0.53 vs 0.29 for instar-five larvae). 


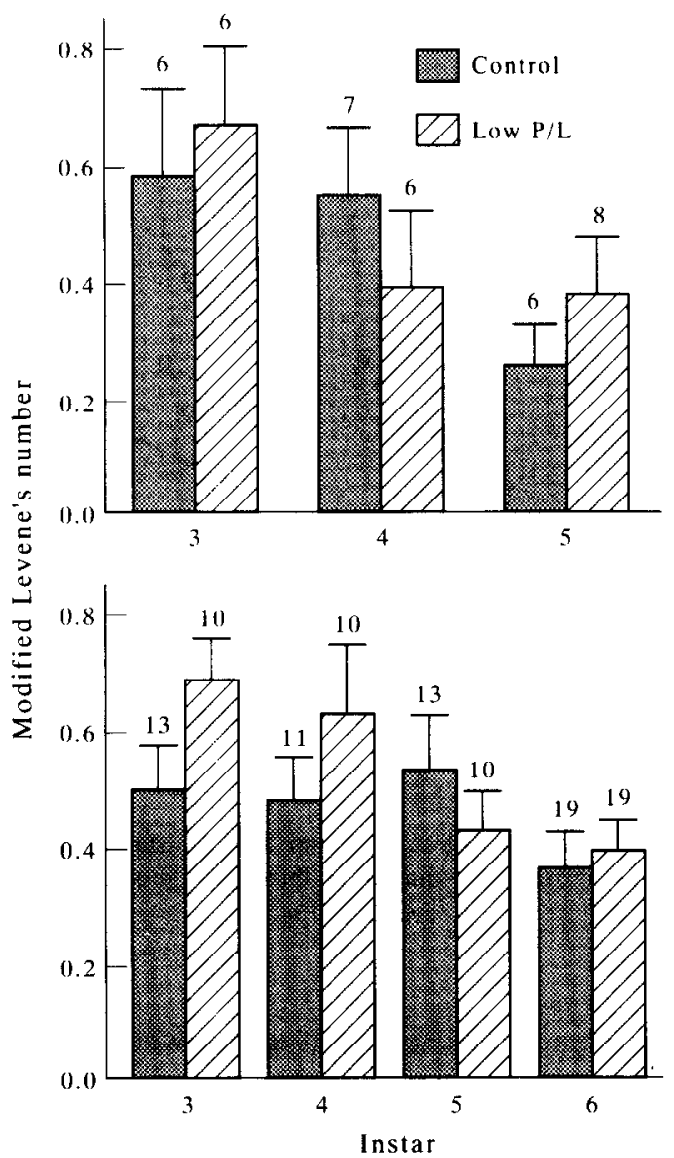

FIGURE 2. Ontogenetic change in food choice behaviour of male (upper panel) and female (lower panel) gypsy moth larvae as measured by the modified Levene's number. This value is the mean difference between the percentage that each cube contributed to the total eaten. Means are plotted with standard errors of the mean; sample sizes are above each bar.

Larvae treated identical cubes in a similar fashion (eating approx. $50 \%$ from each cube when averaged across all individuals). regardless of the nutrient composition of the cubes (nutritionally complete, low protein, or low lipid) but handled complementary cubes differently from the other treatments (Table 3; Chesson's $\alpha$ : $F_{3,61}=3.14, P=0.031$, main and interactive sex effects NS; modified Levene's number: $F_{3,61}=1.04, P=0.380$,

TABLE 3. Food choice behaviour of fourth-instar gypsy moth larvae*

\begin{tabular}{lccc}
\hline Treatment & $n$ & $\begin{array}{c}\text { Chesson's } \\
\alpha\end{array}$ & $\begin{array}{c}\text { Modified } \\
\text { Levene's }\end{array}$ \\
\hline Control & 18 & $0.54^{\mathrm{a}}$ & $0.51^{\mathrm{a}}$ \\
& & $(0.07)$ & $(0.06)$ \\
Comp P/L & 16 & $0.29^{\mathrm{b}}$ & $0.54^{\mathrm{a}}$ \\
& & $(0.06)$ & $(0.09)$ \\
Low P/P & 17 & $0.56^{\mathrm{a}}$ & $0.36^{\mathrm{a}}$ \\
& & $(0.05)$ & $(0.06)$ \\
Low L/L & 18 & $0.49^{\mathrm{a}}$ & $0.52^{\mathrm{a}}$ \\
& & $(0.07)$ & $(0.07)$ \\
\hline
\end{tabular}

*Males and females are pooled. Means are provided with SEM in parentheses. Pairwise comparisons are by contrasts. See text for explanation of Chesson's $\alpha$ and the modified Levene's number. main and interactive sex effects NS). Although the modified Levene's number indicates that Control larvae "preferred" one cube or the other in that they ate primarily from a single cube, Chesson's $\alpha$ demonstrates this selection was essentially random with respect to which of the two identical cubes was chosen. Comp P/L treatment larvae were selective for a particular diet cube in early instars (the high protein/low lipid cube). In early instars as much as $84 \%$ of the total food eaten came from the high protein/low lipid cube, but in later instars this fraction fell below $50 \%$.

\section{Protein and lipid intake}

Chesson's $\alpha$ and the modified Levene's number demonstrate that food selection behaviour changed during ontogeny. What is the outcome of selection behaviour in terms of quantities and ratios of ingested protein and lipid? Larvae within the Control, Low $\mathrm{P} / \mathrm{P}$ and Low L/L treatments received identical diet cubes, and so were confined to specific ratios of protein and lipid ["rails" in the terminology of Raubenheimer and Simpson (1993)]. In contrast, larvae provided complementary diet cubes were able to set for themselves the amounts of protein and lipid ingested across a much broader range of ratios. The selected ratios can be compared over the developmental period and with the fixed ratios in the Control, Low $\mathrm{P} / \mathrm{P}$ and Low $\mathrm{L} / \mathrm{L}$ treatments.

Based on the null expectation that larvae in the Comp $\mathrm{P} / \mathrm{L}$ treatment would consume equal amounts of the complementary cubes, larvae mixed the cubes so as to obtain a lower lipid:protein ratio than expected during the third instar (Fig. 3; most points lie below the expected ratio), and a higher lipid:protein ratio during

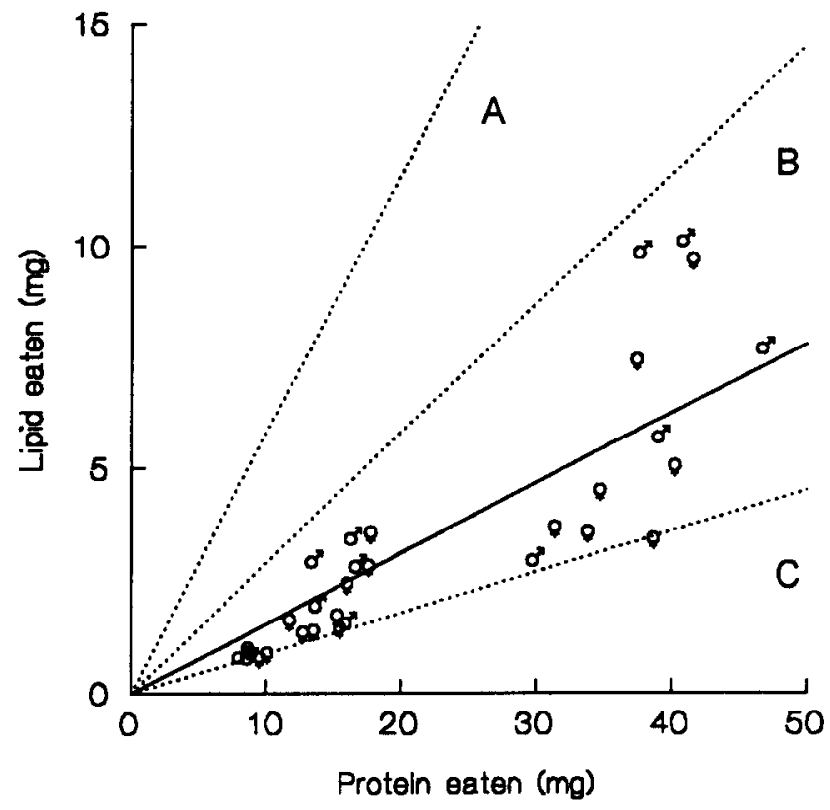

FIGURE 3. Amounts of protein and lipid consumed by male and female gypsy moth larvae during the third instar. The dotted lines indicate the ratios imposed by the Low $\mathrm{P} / \mathrm{P}(\mathrm{A})$, Control (B) and Low $\mathrm{L} / \mathrm{L}$ (C) treatments. The solid line denotes the expected intake by larvae in the Comp $\mathrm{P} / \mathrm{L}$ treatment, assuming $50 \%$ of the total intake comes from each of the complementary diet cubes. 
TABLE 4. ANOVAs of growth measures and nutritional indices during instars 3-5 for male gypsy moth larvae

\begin{tabular}{|c|c|c|c|c|}
\hline Index & Source & d.f. & $F$ & $P$ \\
\hline \multirow{5}{*}{$\mathrm{RCR}$} & Treatment & 1 & 3.15 & 0.086 \\
\hline & Instar & 2 & 73.23 & $<0.0001$ \\
\hline & Treatment & & & \\
\hline & $x$ instar & 2 & 0.62 & 0.543 \\
\hline & Error & 30 & & \\
\hline \multirow[t]{5}{*}{$\mathrm{AD}$} & Treatment & 1 & 0.47 & 0.496 \\
\hline & Instar & 2 & 2.84 & 0.074 \\
\hline & Treatment & & & \\
\hline & $x$ instar & 2 & 4.28 & 0.023 \\
\hline & Error & 30 & & \\
\hline \multirow[t]{5}{*}{ ECD } & Treatment & 1 & 1.08 & 0.307 \\
\hline & Instar & 2 & 3.04 & 0.063 \\
\hline & Treatment & & & \\
\hline & $x$ instar & 2 & 0.05 & 0.059 \\
\hline & Error & 30 & & \\
\hline \multirow[t]{5}{*}{ ECI } & Treatment & 1 & 2.84 & 0.102 \\
\hline & Instar & 2 & 6.54 & 0.004 \\
\hline & Treatment & & & \\
\hline & $x$ instar & 2 & 1.27 & 0.294 \\
\hline & Error & 30 & & \\
\hline \multirow[t]{5}{*}{ RGR } & Treatment & 1 & 0.93 & 0.344 \\
\hline & Instar & 2 & 78.42 & $<0.0001$ \\
\hline & Treatment & & & \\
\hline & $x$ instar & 2 & 1.38 & 0.267 \\
\hline & Error & 30 & & \\
\hline
\end{tabular}

subsequent instars (Fig. 4; most points lie above the expected ratio). Larvae provided complementary diet cubes ate less lipid per unit protein than did larvae given only the control diet, which contained high concentrations of both protein and lipid (Figs 3 and 4; most points lie below that of the Control "rail"). Both males and females exhibited the same trends. All selected ratios, by necessity, lie within the limits imposed by the individual cubes, depicted by the Low P/P and Low L/L "rails".

\section{Food consumption and utilization}

Numerous limitations of gravimetric indices exist (van Loon, 1991); of particular relevance in this study is the

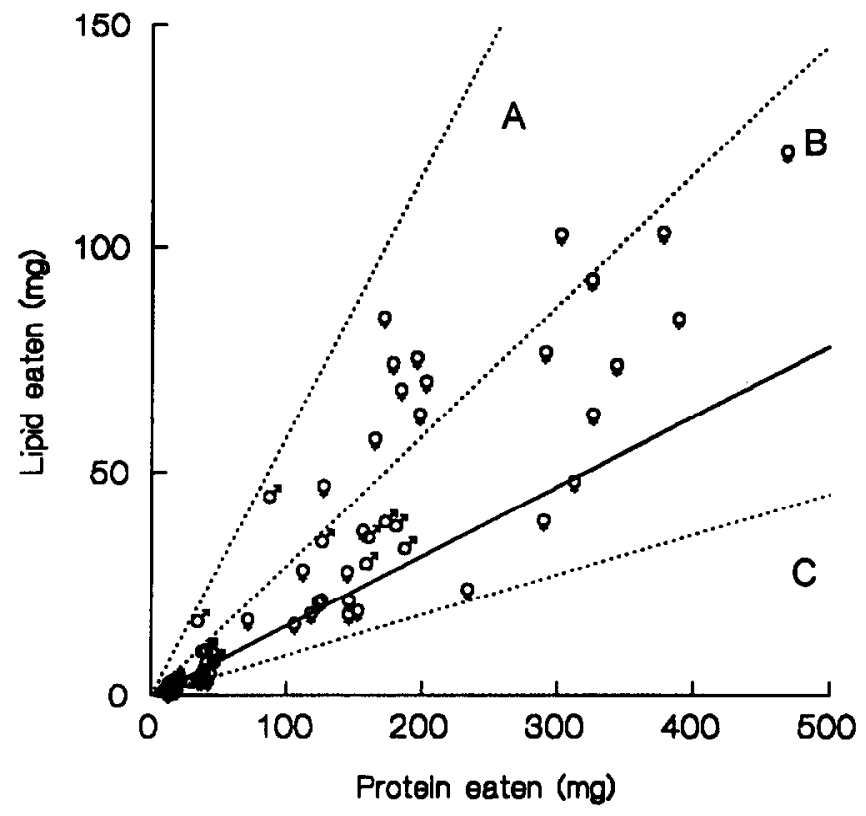

FIGURE 4. Amounts of protein and lipid consumed by male and female gypsy moth larvae during the third through sixth instars. Lines are as in Fig. 3.

magnification of measurement errors when the amount of food provided to individuals is far in excess of what is consumed (Schmidt and Reese, 1986). Unfortunately, in choice experiments where strong preferences/aversions are exhibited it is impossible to ensure that a large proportion of food that is provided is eaten. Because larvae tended to feed more equally from the two diet cubes in (1) later instars, and (2) the Comp P/L treatment, error in calculated indices likely is less in these cases. For this reason, caution is needed when interpreting differences in indices across instars and among treatments.

Male larvae from Control and Comp $P / L$ treatments did not differ in any of the consumption, utilization or growth indices (Tables 4 and 5). Indices were different among instars; as larvae advanced through the juvenile

TABLE 5. Growth and nutritional indices during instars 3-5 for male gypsy moth larvae in Control and Comp P/L treatments*

\begin{tabular}{|c|c|c|c|c|c|c|c|c|c|}
\hline \multirow[b]{2}{*}{ Treatment } & \multirow[b]{2}{*}{ Instar } & \multirow[b]{2}{*}{$n$} & \multicolumn{7}{|c|}{ Index } \\
\hline & & & $\mathbf{R C R}$ & $A D$ & ECD & ECI & RGR & $\begin{array}{c}\text { Mass } \\
\text { gained } \\
(\mathrm{mg})\end{array}$ & $\begin{array}{l}\text { Instar } \\
\text { duration } \\
\text { (days) }\end{array}$ \\
\hline \multirow[t]{3}{*}{ Control } & 3 & 6 & $\begin{array}{c}2.16 \\
(0.12)\end{array}$ & $\begin{array}{l}32.1 \\
(0.8)\end{array}$ & $\begin{array}{l}55.0 \\
(2.6)\end{array}$ & $\begin{array}{l}17.6 \\
(0.7)\end{array}$ & $\begin{array}{c}0.381 \\
(0.027)\end{array}$ & $\begin{array}{c}9.6 \\
(0.4)\end{array}$ & $\begin{array}{c}3.3 \\
(0.2)\end{array}$ \\
\hline & 4 & 7 & $\begin{array}{c}1.60 \\
(0.12)\end{array}$ & $\begin{array}{l}31.8 \\
(1.3)\end{array}$ & $\begin{array}{l}55.7 \\
(4.4)\end{array}$ & $\begin{array}{c}17.4 \\
(0.8)\end{array}$ & $\begin{array}{c}0.280 \\
(0.027)\end{array}$ & $\begin{array}{c}25.9 \\
(2.3)\end{array}$ & $\begin{array}{c}3.8 \\
(0.3)\end{array}$ \\
\hline & 5 & 6 & $\begin{array}{c}0.70 \\
(0.05)\end{array}$ & $\begin{array}{l}43.1 \\
(4.7)\end{array}$ & $\begin{array}{l}34.0 \\
(4.3)\end{array}$ & $\begin{array}{l}13.7 \\
(1.0)\end{array}$ & $\begin{array}{c}0.093 \\
(0.003)\end{array}$ & $\begin{array}{l}88.9 \\
(6.3)\end{array}$ & $\begin{array}{l}11.7 \\
(0.4)\end{array}$ \\
\hline \multirow[t]{3}{*}{ Comp P/L } & 3 & 5 & $\begin{array}{c}2.01 \\
(0.22)\end{array}$ & $\begin{array}{c}33.2 \\
(1.7)\end{array}$ & $\begin{array}{l}57.5 \\
(5.0)\end{array}$ & $\begin{array}{l}18.8 \\
(0.8)\end{array}$ & $\begin{array}{c}0.372 \\
(0.032)\end{array}$ & $\begin{array}{c}9.6 \\
(0.9)\end{array}$ & $\begin{array}{c}3.4 \\
(0.4)\end{array}$ \\
\hline & 4 & 5 & $\begin{array}{c}1.29 \\
(0.12)\end{array}$ & $\begin{array}{l}36.0 \\
(1.5)\end{array}$ & $\begin{array}{c}48.3 \\
(1.7)\end{array}$ & $\begin{array}{l}17.3 \\
(0.6)\end{array}$ & $\begin{array}{c}0.222 \\
(0.020)\end{array}$ & $\begin{array}{c}29.1 \\
(0.4)\end{array}$ & $\begin{array}{c}5.2 \\
(0.5)\end{array}$ \\
\hline & 5 & 7 & $\begin{array}{c}0.64 \\
(0.03)\end{array}$ & $\begin{array}{l}33.5 \\
(2.6)\end{array}$ & $\begin{array}{l}52.7 \\
(8.5)\end{array}$ & $\begin{array}{l}16.4 \\
(1.1)\end{array}$ & $\begin{array}{c}0.107 \\
(0.012)\end{array}$ & $\begin{array}{c}109.1 \\
(3.1)\end{array}$ & $\begin{array}{l}11.6 \\
(0.8)\end{array}$ \\
\hline
\end{tabular}

${ }^{*}$ Means are provided with SEM in parentheses. 
TABLE 6. ANOVAs of growth measures and nutritional indices during instars 3-6 for female gypsy moth larvae reared on Control and Comp $P / L$ treatments

\begin{tabular}{|c|c|c|c|c|}
\hline Index & Source & d.f. & $F$ & $P$ \\
\hline \multirow[t]{5}{*}{$\mathrm{RCR}$} & Treatment & 1 & 6.45 & 0.013 \\
\hline & Instar & 3 & 165.67 & $<0.0001$ \\
\hline & Treatment & & & \\
\hline & $x$ instar & 3 & 0.94 & 0.424 \\
\hline & Error & 86 & & \\
\hline \multirow[t]{5}{*}{$\mathrm{AD}$} & Treatment & 1 & 0.65 & 0.423 \\
\hline & Instar & 3 & 10.16 & $<0.0001$ \\
\hline & Treatment & & & \\
\hline & $x$ instar & 3 & 1.99 & 0.121 \\
\hline & Error & 86 & & \\
\hline \multirow[t]{5}{*}{ ECD } & Treatment & 1 & 5.01 & 0.028 \\
\hline & Instar & 3 & 37.84 & $<0.0001$ \\
\hline & Treatment & & & \\
\hline & $x$ instar & 3 & 0.09 & 0.963 \\
\hline & Error & 86 & & \\
\hline \multirow[t]{5}{*}{ ECI } & Treatment & 1 & 0.12 & 0.725 \\
\hline & Instar & 3 & 40.24 & $<0.0001$ \\
\hline & Treatment & & & \\
\hline & $x$ instar & 3 & 7.15 & $<0.002$ \\
\hline & Error & 86 & & \\
\hline \multirow[t]{5}{*}{ RGR } & Treatment & 1 & 10.24 & 0.002 \\
\hline & Instar & 3 & 209.40 & $<0.0001$ \\
\hline & Treatment & & & \\
\hline & $x$ instar & 3 & 1.79 & 0.156 \\
\hline & Error & 86 & & \\
\hline
\end{tabular}

period, RCR declined, AD increased slightly (Control) or remained constant (Comp $P / L)$, while ECD and ECI declined. Absolute dry mass gain increased with successive instars, while instar duration increased and RGR decreased (Table 5). Larvae in the Comp P/L treatment tended to be more stable in indices across instars than larvae in the Control group.

In contrast, female larvae showed a significant treatment effect on all indices except $\mathrm{AD}$ and $\mathrm{ECI}$, and all indices strongly differed across instars (Tables 6 and 7). Significant treatment $x$ instar effects were present for ECI. Overall, RCR declined, AD increased (more stable across instars in the Comp P/L than Control treatment), while ECD and ECI declined with successive instars. Dry mass gained increased as did instar duration, yielding a much lower RGR during instar six than in instar three. As with males, grcater stability in several indices was evident in larvae provided a choice of complementary diet cubes (Table 7).

Comparison of effects among all four diet treatments during instar four indicated larvae did not differ significantly in RGR $\left(F_{3,58}=1.11, P=0.353\right)$ or ECD $\left(F_{3,58}=1.60, P=0.199\right)$, and differed only marginally in instar duration $\left(F_{3,58}=2.72, P=0.052\right)$ in ANOVA models with treatment, sex and treatment $x$ sex terms. Larvae provided only low protein/high lipid food ate at a significantly higher rate (RCR: $F_{3,58}=13.16$, $P<0.0001)$, had lower AD $\left(F_{3,58}=70.92, P<0.0001\right)$, lower ECI $\left(F_{3,58}=88.44, P<0.0001\right)$ and gained less dry mass $\left(F_{3.58}=4.84, P=0.004\right)$ than larvae on the other three diet treatments. Males and females differed only in RCR $\quad\left(F_{1,58}=8.35, \quad P=0.005\right), \quad R G R \quad\left(F_{1,58}=12.72\right.$, $P<0.001)$ and instar duration $\left(F_{1,58}=9.63, P=0.003\right)$ such that females had higher RCR, higher RGR and shorter instar duration. No significant treatment $x$ sex interaction terms were significant (all $P>0.1$ except instar duration, for which $P=0.066$ ).

\section{Juvenile growth, pupal period and adult longevity}

Insects provided complementary diet cubes did not exhibit a strong or consistent growth or survival advantage over insects in other treatments. Juvenile period was prolonged on the low protein diet treatment (Low $\mathbf{P} / \mathbf{P}$ ) for both males and females (males, Kruskal-Wallis: 53.8, d.f. $=3, P<0.0001 ;$ females, ANOVA: $F_{3,210}=61.8$,

TABLE 7. Growth and nutritional indices during instars 3-6 for female gypsy moth larvae reared on Control and Comp P/L treatments*

\begin{tabular}{|c|c|c|c|c|c|c|c|c|c|}
\hline \multirow[b]{2}{*}{ Treatment } & \multirow[b]{2}{*}{ Instar } & \multirow[b]{2}{*}{$n$} & \multicolumn{7}{|c|}{ Index } \\
\hline & & & RCR & $\mathrm{AD}$ & ECD & $\mathrm{ECI}$ & RGR & $\begin{array}{c}\text { Mass } \\
\text { gained } \\
(\mathrm{mg})\end{array}$ & $\begin{array}{c}\text { Instar } \\
\text { duration } \\
\text { (days) }\end{array}$ \\
\hline \multirow[t]{4}{*}{ Control } & 3 & 13 & $\begin{array}{c}1.96 \\
(0.12)\end{array}$ & $\begin{array}{l}30.8 \\
(1.2)\end{array}$ & $\begin{array}{l}61.1 \\
(3.8)\end{array}$ & $\begin{array}{l}18.3 \\
(0.5)\end{array}$ & $\begin{array}{c}0.36 \\
(0.02)\end{array}$ & $\begin{array}{c}8.8 \\
(0.6)\end{array}$ & $\begin{array}{c}3.5 \\
(0.3)\end{array}$ \\
\hline & 4 & 11 & $\begin{array}{c}1.73 \\
(0.08)\end{array}$ & $\begin{array}{l}31.4 \\
(0.9)\end{array}$ & $\begin{array}{l}55.6 \\
(1.5)\end{array}$ & $\begin{array}{l}17.4 \\
(0.4)\end{array}$ & $\begin{array}{c}0.30 \\
(0.01)\end{array}$ & $\begin{array}{l}27.0 \\
(1.3)\end{array}$ & $\begin{array}{c}3.6 \\
(0.2)\end{array}$ \\
\hline & 5 & 13 & $\begin{array}{c}0.98 \\
(0.08)\end{array}$ & $\begin{array}{l}42.1 \\
(1.4)\end{array}$ & $\begin{array}{l}50.3 \\
(3.1)\end{array}$ & $\begin{array}{l}20.8 \\
(1.0)\end{array}$ & $\begin{array}{c}0.20 \\
(0.02)\end{array}$ & $\begin{array}{l}96.8 \\
(5.9)\end{array}$ & $\begin{array}{c}6.2 \\
(0.6)\end{array}$ \\
\hline & 6 & 17 & $\begin{array}{c}0.48 \\
(0.02)\end{array}$ & $\begin{array}{l}50.7 \\
(5.0)\end{array}$ & $\begin{array}{l}37.7 \\
(6.1)\end{array}$ & $\begin{array}{l}15.2 \\
(0.6)\end{array}$ & $\begin{array}{c}0.073 \\
(0.004)\end{array}$ & $\begin{array}{l}278.3 \\
(22.1)\end{array}$ & $\begin{array}{l}15.1 \\
(0.4)\end{array}$ \\
\hline \multirow[t]{4}{*}{ Comp P/L } & 3 & 10 & $\begin{array}{c}2.14 \\
(0.05)\end{array}$ & $\begin{array}{l}36.5 \\
(1.0)\end{array}$ & $\begin{array}{l}54.6 \\
(1.6)\end{array}$ & $\begin{array}{l}19.8 \\
(0.5)\end{array}$ & $\begin{array}{c}0.42 \\
(0.01)\end{array}$ & $\begin{array}{c}9.9 \\
(0.6)\end{array}$ & $\begin{array}{c}3.0 \\
(0.3)\end{array}$ \\
\hline & 4 & 9 & $\begin{array}{c}1.77 \\
(0.14)\end{array}$ & $\begin{array}{l}39.0 \\
(2.0)\end{array}$ & $\begin{array}{l}51.4 \\
(4.0)\end{array}$ & $\begin{array}{l}19.7 \\
(1.2)\end{array}$ & $\begin{array}{c}0.34 \\
(0.02)\end{array}$ & $\begin{array}{l}38.0 \\
(4.8)\end{array}$ & $\begin{array}{c}3.4 \\
(0.3)\end{array}$ \\
\hline & 5 & 9 & $\begin{array}{c}1.28 \\
(0.09)\end{array}$ & $\begin{array}{l}44.4 \\
(1.1)\end{array}$ & $\begin{array}{l}44.1 \\
(1.2)\end{array}$ & $\begin{array}{l}19.5 \\
(0.3)\end{array}$ & $\begin{array}{c}0.25 \\
(0.02)\end{array}$ & $\begin{array}{l}99.0 \\
(4.8)\end{array}$ & $\begin{array}{c}4.6 \\
(0.3)\end{array}$ \\
\hline & 6 & 14 & $\begin{array}{c}0.60 \\
(0.02)\end{array}$ & $\begin{array}{l}46.1 \\
(5.1)\end{array}$ & $\begin{array}{l}27.9 \\
(2.5)\end{array}$ & $\begin{array}{l}11.7 \\
(0.7)\end{array}$ & $\begin{array}{l}0.070 \\
(0.004)\end{array}$ & $\begin{array}{l}280.5 \\
(22.8)\end{array}$ & $\begin{array}{l}15.0 \\
(0.5)\end{array}$ \\
\hline
\end{tabular}

*Means are provided with SEM in parentheses. 
TABLE 8. Growth measures, pupal period and adult longevity of male and female gypsy moth reared on Control, Comp P/L, Low P/P and Low L/L treatments*

\begin{tabular}{|c|c|c|c|c|c|}
\hline Sex & $\begin{array}{c}\text { Diet } \\
\text { treatment }\end{array}$ & $\begin{array}{c}\text { Juvenile } \\
\text { period } \\
\text { (days) }\end{array}$ & $\begin{array}{l}\text { Pupal } \\
\text { mass } \\
(\mathrm{mg})\end{array}$ & $\begin{array}{l}\text { Pupal } \\
\text { period } \\
\text { (days) }\end{array}$ & $\begin{array}{c}\text { Adult } \\
\text { longevity } \\
\text { (h) }\end{array}$ \\
\hline \multirow[t]{4}{*}{ Male } & Control & $\begin{array}{l}38.8^{\mathrm{a}} \\
(1.04) \\
(25)\end{array}$ & $\begin{array}{c}105.0^{\mathrm{a}} \\
(4.07) \\
(31)\end{array}$ & $\begin{array}{l}13.3^{\mathrm{a}} \\
(0.39) \\
(18)\end{array}$ & $\begin{array}{c}95.8^{\mathrm{a}} \\
(14.58) \\
(4)\end{array}$ \\
\hline & Comp P/L & $\begin{array}{l}38.0^{\mathrm{a}} \\
(0.70) \\
(33)\end{array}$ & $\begin{array}{c}111.1^{\mathrm{a}} \\
(3.96) \\
(38)\end{array}$ & $\begin{array}{l}12.9^{\mathrm{a}} \\
(0.33) \\
(31)\end{array}$ & $\begin{array}{c}104.6^{\mathrm{a}} \\
(7.14) \\
(13)\end{array}$ \\
\hline & Low $\mathbf{P} / \mathbf{P}$ & $\begin{array}{c}45.2^{\mathrm{b}} \\
(0.79) \\
(39)\end{array}$ & $\begin{array}{c}98.9^{\mathrm{a}} \\
(4.06) \\
(37)\end{array}$ & $\begin{array}{l}11.1^{\mathrm{b}} \\
(0.26) \\
(35)\end{array}$ & $\begin{array}{l}94.4^{\mathrm{a}} \\
(5.60) \\
(30)\end{array}$ \\
\hline & Low $\mathrm{L} / \mathrm{L}$ & $\begin{array}{l}37.2^{2} \\
(0.51) \\
(38)\end{array}$ & $\begin{array}{c}135.0^{2} \\
(3.83) \\
(38)\end{array}$ & $\begin{array}{l}12.0^{\mathrm{ab}} \\
(1.10) \\
(9)\end{array}$ & $\begin{array}{l}103.8^{\mathrm{a}} \\
(8.53) \\
(6)\end{array}$ \\
\hline \multirow[t]{4}{*}{ Female } & Control & $\begin{array}{l}44.7^{\mathrm{a}} \\
(0.37) \\
(62)\end{array}$ & $\begin{array}{l}333.4^{\mathrm{a}} \\
(13.3) \\
(62)\end{array}$ & $\begin{array}{c}9.8^{\mathrm{a}} \\
(0.16) \\
(57)\end{array}$ & $\begin{array}{c}95.2^{\mathrm{a}} \\
(8.8) \\
(41)\end{array}$ \\
\hline & Comp P/L & $\begin{array}{l}43.4^{\mathrm{ac}} \\
(0.43) \\
(48)\end{array}$ & $\begin{array}{l}343.2^{\mathrm{a}} \\
(14.7) \\
(50)\end{array}$ & $\begin{array}{l}10.1^{\mathrm{a}} \\
(0.19) \\
(45)\end{array}$ & $\begin{array}{c}100.6^{\mathrm{a}} \\
(7.83) \\
(31)\end{array}$ \\
\hline & Low $\mathrm{P} / \mathrm{P}$ & $\begin{array}{l}50.3^{\mathrm{b}} \\
(0.52) \\
(45)\end{array}$ & $\begin{array}{c}228.1^{\circ} \\
(8.44) \\
(43)\end{array}$ & $\begin{array}{c}9.0^{\mathrm{b}} \\
(0.14) \\
(37)\end{array}$ & $\begin{array}{l}91.7^{\mathrm{a}} \\
(4.50) \\
(27)\end{array}$ \\
\hline & Low $\mathrm{L} / \mathrm{L}$ & $\begin{array}{l}42.4^{c} \\
(0.40) \\
(59)\end{array}$ & $\begin{array}{l}377.3^{\mathrm{a}} \\
(12.87) \\
(59)\end{array}$ & $\begin{array}{c}10.2^{\mathrm{a}} \\
(0.16) \\
(44)\end{array}$ & $\begin{array}{l}96.1^{\mathrm{a}} \\
(12.78) \\
(34)\end{array}$ \\
\hline
\end{tabular}

*Means are provided with SEM and sample size in parentheses. Pairwise comparisons are by contrasts. Values followed by different letters are different at a significance level of $\alpha=0.05 / 6$, adjusting for multiple comparisons.

$P<0.0001)$ and, for females, was slightly shorter on low lipid diet (Low L/L) than on Control diet (Table 8). Relative to Low $\mathrm{P} / \mathrm{P}$ larvae, the juvenile period of Comp $P / L$ larvae was shorter, but was roughly equal to that achieved by Control and Low $\mathrm{L} / \mathrm{L}$ larvae.

Pupal dry mass of males differed only marginally among the four diet treatments (ANOVA: $F_{3,140}=2.71$, $P=0.047$ ) with pupae from the Low $\mathrm{P} / \mathrm{P}$ treatment being the lightest and those from the Low $\mathrm{L} / \mathrm{L}$ treatment being the heaviest (Table 8). Pupal mass of females was more strongly affected by diet treatments (KruskalWallis test statistic $=53.1$, d.f. $=3, P<0.0001$ ). Pupal mass of females was lowest on the Low P/P treatment and highest on the Low $L / L$ treatment. Mean pupal mass of Comp $P / L$ larvae tended to be higher than that of Control and Low P/P larvae, but less than the pupal mass of Low $\mathrm{L} / \mathrm{L}$ larvae. These differences were not statistically significant, but are consistent with the lower lipid intake by Comp P/L larvae relative to Control larvae.

Pupal period differed significantly among treatments for males (Kruskal-Wallis: 20.4, d.f. $=3, P<0.001$ ) and females (ANOVA: $F_{3,179}=8.8, P<0.0001$ ). For both sexes, pupal period was shortest for larvae reared on low protein diet. However, further investigation revealed that this apparent treatment effect was mediated by differences in juvenile period and only indirectly was caused by the treatments. In an ANCOVA model of pupal period with treatment, juvenile period and sex, treatment did not explain a significant portion of the variance in pupal period (ANCOVA: $F_{3,173}=0.81$, $P=0.488$ ), whereas juvenile period was highly significant $\left(F_{1,173}=70.68, P<0.0001\right)$. Variation in juvenile period explained significant variance in pupal period $[P=0.091$ for control, $P<0.001$ for all other treatments in models within each of the four diet treatments (with sex included as a factor)]. Longer juvenile period was negatively correlated with pupal period for both males and females [Pearson's correlation coefficient $=-0.66, n=93, P<0.0001$ (males); -0.51 , $n=183, P<0.0001$ (females)]. Hence, larvae late in reaching the pupal stage partially made up for slow growth by rapid pupal development. Possibly, this is a mechanism by which synchronous emergence is maintained (especially crucial to the fitness of individuals in species such as the gypsy moth that have short-lived, non-feeding adult stages).

Adult longevity was highly variable within diet treatments and did not differ among treatments for males (ANOVA: $F_{3,49}=0.48, P=0.695$ ) or females (KruskalWallis: 3.07 , d.f. $=3, P=0.381$ ). However, adult period was significantly negatively correlated with pupal period for females (Pearson's correlation coefficient $=-\mathbf{0 . 3 0}$, $n=130, P<0.001)$, although not for males $(-0.07$, $n=52, P=0.637)$. This likely reflects the fact that the pupal and adult stages "compete" for energy reserves accumulated during the larval stage.

\section{DISCUSSION}

Both male and female gypsy moth larvae exhibited a change in apparent preference during ontogeny from high protein/low lipid diet towards low protein/high lipid diet, and evidenced a decline in the protein:lipid consumption ratio. Similar shifts in preference have been noted in some aquatic insects (Coffman et al., 1971; Anderson, 1976) and were suggested in an analysis of the nitrogen budget of gypsy moth (Montgomery, 1982). The precise origins of these changes remain unknown, but recent evidence exists that nutritional requirements of some insects change both within and across instars (Simpson and Simpson, 1990). Presumably, the observed shifts in preference by gypsy moth are related to changes in nutrient requirements during juvenile development. In the experiments reported on here, it is important to note that the standard measurement period used ( 3 days) represents different proportions of successive instars. As a result, the observed differences in selection include changes between stadia as well as changes within an instar.

A shift in the relative importance of protein and lipid is compatible with the common observation that laterinstar larvae contain a greater proportion of lipid in their bodies (Slansky and Scriber, 1985). Because the later instars represent the period of maximal weight gain, the composition of pupal and adult tissues should strongly reflect the diet consumed during the later instars. Energy 
storage may become more important in later-instar gypsy moth because the future energetic needs of the non-feeding pupal and adult stages must be met by fat reserves accumulated during the larval stage, and dietary lipids are a richer source of energy than dietary proteins. In addition, certain fatty acids (linoleic and linolenic acids in particular) are critical to successful pupal/adult ecdysis (Dadd, 1985) and are known to differ in concentration as a result of different diets (Barlow, 1966; Hanson et al., 1983, 1985). The importance of fatty acids to later instars has been demonstrated by complete alleviation of metamorphic failure by provision with linolenic acid only late in juvenile development (Rock et al., 1965; Kato, 1978). Although pupae in the Low $\mathrm{L} / \mathrm{L}$ treatment that received only low lipid food were large, a relatively high proportion of adults with curled or otherwise deformed wings was noted.

The observation that males ate more from the low protein/high lipid diet than did females is consistent with the life history of gypsy moth. Although both sexes develop wings, only males fly, so that energy requirements of males are likely to be far greater than for females. The difference in preference between males and females was small (2-4\% when comparing Chesson's $\alpha$ in the third, fourth, and ultimate instars), but summed over the entire juvenile period could result in substantial differences in the amount of protein and lipid consumed.

Two important predictions arise from this sexdependent behaviour. First, males and females may forage for leaves of slightly different nutrient composition. Depending on the variance and covariance of nutrients among leaves, this could be manifest by foraging on different host species, plants, or locations within a host. Because sexual dimorphism does not appear until the advanced instars, the extent to which populations are spatially structured with respect to sex is unknown and difficult to ascertain. Second, changes in nutrient composition over time may affect the growth and foraging behaviour of males and females differently. Seasonal or induced changes in foliage nutrient composition, for example, may impact females more than males. Sexual differences in relative rates of consumption and food utilization have been noted (Slansky and Scriber, 1985), but little is known of sexual differences in foraging behaviour in the field.

If the ontogenetic change in observed behaviour is an adaptive response, then a logical expectation is that larvae reared on the Comp $P / L$ diet treatment would have more favourable proximate measures of fitness than those reared on other diet treatments. Contrary to this expectation, there was no strong, consistent growth benefit accrued by larvae with access to complementary diet cubes. Comp P/L larvae grew faster and larger than Low $\mathbf{P} / \mathbf{P}$ larvae but performed equally well as Control and Low $L / L$ larvae. This reflects, in part, the fact that the protein:lipid ratios chosen by Comp $\mathrm{P} / \mathrm{L}$ larvae were closer to those provided by the Control and Low $\mathrm{L} / \mathrm{L}$ diets than the Low P/P diet. One cannot assume, however, that there were no fitness differences. Conceivably, the mass gained by larvae provided different cubes was more effectively translated into survival and egg production than was the mass gained by Low $\mathrm{L} / \mathrm{L}$ and Control larvae that were each provided identical cubes. In particular, gypsy moth larvae reared on high protein diets are known to contain a larger fraction of protein in their bodies than those reared on low protein diet (Stockhoff, 1991), and protein may contribute less to fitness per unit mass than does lipid. Also, as noted above with regard to wing deformity, innumerable diet effects are possible that affect fitness but are not manifest in standard growth measures. More detailed measures than taken here will be necessary to determine conclusively the benefit of selective feeding to fitness.

The relative lack of difference in performance between treatments is a reflection of the efficiency of nutritional compensatory mechanisms. Although larvae provided with complementary diet cubes had the freedom to match their nutritional target ratio by both pre-ingestive (behavioural) and post-ingestive (physiological) mechanisms, the post-ingestive mechanisms to which Control, Low $P / P$ and Low $L / L$ larvae were restricted apparently were sufficient to achieve approximately the same growth. It is important that larvae responded behaviourally despite the lack of a strong benefit of doing so. Pre-ingestive compensation may be a more efficient means to accommodate nutritional variation than postingestive compensation, although factors such as predation risk could play a significant, deciding role. Presumably, the value of behavioural compensation increases as available foods become more extreme in their nutrient concentrations.

Several of the food utilization indices strongly increased or declined over successive instars. Interestingly, two of these trends were opposite from those most commonly observed for juvenile insects. AD usually tends to decrease from early to late instars, while ECD tends to increase (Slansky and Scriber, 1985). For the gypsy moth, AD increased (more for females) while ECD declined. However, AD and ECD were more stable in the Comp $\mathrm{P} / \mathrm{L}$ treatment in which larvae had a choice of diet cubes. One possible explanation for the greater shifts in AD and ECD by Control larvae is that the Control insects did not have the option to compensate via selectivity for changes in digestive and utilization capacity, as they did in the Comp $\mathrm{P} / \mathrm{L}$ treatment. It is important to note that most experiments where changes in utilization efficiencies have been observed involve no-choice situations. Larvae may be better able to compensate for ontogenetic changes when given the opportunity to select. Under certain circumstances, changes in food utilization efficiency may be artifacts that result from failure to compensate behaviourally.

Although differences in the acceptability or suitability of a plant or plant part are known to depend on the growth stage of an insect (Simpson and Simpson, 1990; Waldbauer and Friedman, 1991), the underlying causes of such changes generally are not clear. Plant phenology and availability, environmental conditions, susceptibility 
to predators or parasitoids, physical constraints and changing nutrient demands all may be important to varying degrees. This study is one of the first to document in a folivorous Lepidopteran a steady change during larval ontogeny in food selection behaviour for specific nutrients that is independent of biotic and abiotic factors external to the insect. A likely causal factor behind this change in food selection is adjustment to shifting nutrient demands.

\section{REFERENCES}

Anderson N. H. (1976) Carnivory by an aquatic detritivore, Clistoronia magnifica (Trichoptera: Limnephilidae). Ecology 57, 1081-1085.

Barlow J. S. (1966) Effects of diet on the composition of body fat in Lucilia sericata. Nature 212, 1478-1479.

Chesson J. (1983) The estimation and analysis of preference and its relationship to foraging models. Ecology 64, 1297-1304.

Coffman W. P., Cummins K. W. and Weycheck J. W. (1971) Energy flow in a woodland stream ecosystem. I. Tissue support trophic structure of the autumnal community. Arch. Hydrobiol. 68, 232-276.

Dadd R. H. (1985) Nutrition: organisms. In Comprehensive Insect Physiology, Biochemistry and Pharmacology (Eds Kerkut G. A. and Gilbert L. I.), Vol. 4, pp. 313-390. Pergamon Press, Oxford.

Hanson B. J., Cummins K. W., Cargill A. S. and Lowry R. R. (1983) Dietary effects on lipid and fatty acid composition of Clistoronia magnifica (Trichoptera: Limnephilidae). Freshw. Invert. Biol. 2, 2-15.

Hanson B. J., Cummins K. W., Cargill A. S. and Lowry R. R. (1985) Lipid content, fatty acid composition, and the effect of diet on fats of aquatic insects. Comp. Biochem. Physiol. 80B, 257-276.

Kato M. (1978) Phenols as indispensable components of the synthetic diet of the silkworm, Bombyx mori. Entomologia exp. appl. 24, 485-490.

Lechowicz M. J. (1982) The sampling characteristics of electivity indices. Oecologia 52, 22-30.

van Loon J. J. A. (1991) Measuring food utilization in plant-feeding insects: toward a metabolic and dynamic approach. In Insect-Plant Interactions (Ed. Bernays E.), pp. 79-124. CRC Press, Boca Raton, FL.

Montgomery M. E. (1982) Life-cycle nitrogen budget for the gypsy moth, Lymantria dispar reared on artificial diet. J. Insect Physiol. 28, $437-442$.
Odell T. M., Butt C. A. and Bridgeforth A. W. (1985) Lymantria dispar. In Handbook of Insect Rearing (Eds Singh P. and Moore R. F.), Vol. 2, pp. 355-367. Elsevier, Amsterdam.

Raubenheimer D. and Simpson S. J. (1993) The geometry of compensatory feeding in the locust. Physiol. Ent. In press.

Rock G. C., Patton R. L. and Glass E. H. (1965) Studies of the fatty acid requirements of Argyrotaenia velutinana (Walker). J. Insect Physiol. 11, 91-101.

Schmidt D. J. and Reese J. C. (1986) Sources of error in nutritional index studies of insects on artificial diet. J. Insect Physiol. 32, 193-198.

Simpson S. J. and Simpson C. L. (1990) The mechanisms of nutritional compensation by phytophagous insects. In Insect-Plant Interactions (Ed. Bernays E. A.), Vol. 2, pp. 111-160. CRC Press, Boca Raton, Fl,

Slansky F. Jr and Scriber J. M. (1985) Food consumption and utilization. In Comprehensive Insect Physiology, Biochemistry and Pharmacology (Eds Kerkut G. A. and Gilbert L. I.), Vol. 4, pp. 87-163. Pergamon Press, Oxford.

Stockhoff B. A. (1991) Starvation resistance of gypsy moth, Lymantria dispar (L.) (Lepidoptera: Lymantriidae): tradeoffs among growth, body size, and survival. Oecologia 88, 422429.

Van Valen L. (1978) The statistics of variation. Evol. Theory 4, 33-43. Waldbauer G. P. (1968) The consumption and utilization of food by insects. Adv. Insect Physiol. 5, 229-288.

Waldbauer G. P. and Friedman S. (1988) Dietary self-selection by insects. In Endocrinological Frontiers in Physiological Insect Ecology (Eds Senhal F., Zabza A. and Denlinger D. L.), pp. 403-422. Wroclaw Tech Univ., Wroclaw.

Waldbauer G. P. and Friedman S. (1991) Self-selection of optimal diets by insects. A. Rev. Entl. 36, 43-63.

Acknowledgements -I thank A. Kessel and C. Pletcher for assistance in rearing larvae and collecting data. I also am indebted to $C$. Bach, G. Belovsky, M. Martin, B. Rathcke, J. Witter and two anonymous reviewers for criticism of the manuscript. The work was supported by McIntire-Stennis grant MICY-00078 to G. Belovsky and J. Witter, NSF grant BSR-8904043 to M. Martin, Sigma Xi Grants-in-Aid of Research, and the Horace H. Rackham School of Graduate Studies. The work is in partial fulfilment of doctoral degree requirements at the University of Michigan. 